European Journal of Probation

University of Bucharest www.ejprob.ro

Vol. 4, No.3, 2012, pp $4-20$

ISSN: $2006-2203$

\title{
Foreigners to Justice? Irregular migrants and foreign national offenders in England and Wales
}

\begin{abstract}
Rob Canton
Nick Hammond ${ }^{1}$

"The facts are these. It is acknowledged that a whole sale immigration from the eastern part of Europe has been going on for some time, and is taking place now. Many of these immigrants are quite destitute and without any trade by which they can earn a living. ... they lower the standard of living among our own working classes. ... This country is rapidly becoming the sink of the most undesirable class of aliens on the Continent." Lord Belpek (HL Deb 28 July 1905 vol. 150 cc749-75)
\end{abstract}

\begin{abstract}
There is a long tradition of blaming foreigners for crime problems in England and Wales. The contemporary manifestation of this centres on suspicion about the involvement in crime of foreign nationals and irregular migrants. General descriptive terms like foreign nationals encompass people in widely diverse circumstances and of different legal immigration statuses. Debates about crime and about the management of movement across national borders have become entangled in political debate, to the detriment of clear thinking about either matter. The rehabilitation principle has a different significance and application for foreign nationals, in practice if not in law. The limited statistics available concerning the involvement of foreign nationals in crime and their treatment by judicial and criminal justice agencies, require more analysis. In criminal justice and sentencing, there are no formal requirements for agencies and courts to bring different principles to their decisions about foreign nationals, but in practice this group of offenders can be disadvantaged. The context of offending by foreign nationals and their distinctive and individual needs are often insufficiently appreciated and too little is done to support rehabilitation and desistance. The perceived political imperative to remove foreign national offenders by deportation distorts any principled approach to policy and practice.
\end{abstract}

Keywords: Foreign Nationals - Irregular migrants - Rehabilitation - England and Wales

\footnotetext{
${ }^{1}$ Rob Canton is Professor in Community and Criminal Justice at De Montfort University, Leicester. Nick Hammond, an Equality Officer, is the foreign national offender lead in London Probation Trust. Email: RCanton@dmu.ac.uk
} 


\section{Background - History, Politics and Definitions}

Over a long period of history, foreign nationals have been cast as a scapegoat to take much of the blame for crime and other social ills in England. Xenophobia and racism have been both the cause and the effect of blaming 'foreigners' in these ways. Rioters in London in the $18^{\text {th }}$ century, for example, protested against Irish migrant workers. Crimes that could be attributed to discernible ethnic or cultural minorities could be a catalyst for violence against the communities concerned. McLynn describes the conviction and execution in 1771 of members of a Jewish gang, commenting "The fact that Jews had been involved in a criminal organization led to virulent outbursts of anti-Semitism and to physical attacks on Jews in London." (1991: 44) Knife crime and garotting (strangulation and robbery), which was a focus of 'moral panic' in the 1860s, were denounced as un-British and accordingly (and groundlessly) attributed to foreigners, with calls for deportations (Davis 1980, Pearson 1983). Even the language of denunciation of offenders betrays this tendency: the word hooligan is believed to be of Irish origin, while the word thug originates in India. It is as if crime represents an alien intrusion upon the ordered tranquillity of British domestic life (Pearson 1983). ${ }^{2}$

In more recent times too political debate about crime has sometimes become entangled with anxieties about immigration - to the detriment of fair-minded and considered debate about either topic - aggravated by racism, insularity and xenophobic traditions in English culture. It is not only political parties of the far right that look to make connections between immigration and crime. In a speech in 2006, Tony Blair juxtaposed anti-social behaviour, crime, asylum, immigration and terrorism in a single speech as if they amounted to a closely related cluster of problems and ended up calling on people to recognise and resist these 'modern forces attacking ... order and peace of mind' (Blair 2006).

The origins of these attitudes are complex, no doubt including Britain's imperial legacy and conceits of national and racial superiority ${ }^{3}$. But they are also a manifestation of the tendency to regard offenders as other - in some significant sense constitutionally different from 'us'. This is among the ways in which we disavow their offending and seek to distance ourselves from it. A corollary of this is that those who are in some identifiable way different can come to be seen as suspicious. This makes people of foreign nationality especially likely to be cast as 'folk devils' and linked - sometimes explicitly, often by insinuation - with many of the 'moral panics' of the day (Cohen 1972).

These 'suitable enemies' (Wacquant 1999) are often aggregated into an undifferentiated group of 'others', distinguished from 'us' variously on ethnic, racial, national or cultural grounds. Thus, since any expression encompasses an widely diverse range of political statuses, as well as many other dimensions of difference, our first difficulty is attempting to identify who is being talked about

\footnotetext{
${ }^{2}$ There is no suggestion that this is a uniquely British phenomenon. Hester and Eglin (1992) give an instructive example of the way in which legislation against drug use in Canada represented a racialisation of what was essentially a social class conflict.

${ }^{3}$ It is possible that the tendency to talk about crime and immigration at the same time has been aggravated too by the fact that until as recently as 2007 when a Ministry of Justice was established, in Britain, as in perhaps no other northern or western European country, the same government minister (the Home Secretary) was responsible for criminal justice and for immigration policy.
} 
when foreign nationals or irregular migrants are discussed ${ }^{4}$. Sometimes the groups designated by these terms overlap although they are, conceptually and in terms of associated legal rights, quite distinct. But while the legal position of irregular migrants and other foreign nationals is altogether different, these distinctions are commonly overlooked by the media and, sometimes perhaps wilfully, blurred in public debate about crime. It is also likely, as we shall discuss, that all offenders who come from other countries - perhaps with families and connections elsewhere and who may be returning to their countries of origin before long - have problems in common, regardless of their legal entitlement to reside. To this extent, the challenges of providing fair and relevant criminal justice services service are sometimes the same for irregular migrants as for other foreign nationals.

The term, 'irregular migrant', has gained popularity in discussions surrounding the interaction of rights / benefits / entitlements, access to public funds and in the criminal justice arena, their potential for removal and deportation should they offend. In the UK context, use of the term 'irregular migrant' needs to be used accurately and appropriately. For example, in the UK context, citizens of European Economic Area (EEA) countries may be termed foreign nationals ${ }^{5}$, but it is misleading and inaccurate to refer to them as irregular migrants when they are exercising Treaty Rights in migrating and living in the UK. The principle of freedom of movement ${ }^{6}$ is a foundational right in the EU / EEA, affirmed and guaranteed by a succession of treaties and agreements and forms a principal component of the EU acquis. Citizens of EEA states, then, may be migrants and temporary visitors and are regular - certainly not 'irregular' - migrants. At the same time, however, as we shall see, EEA citizens convicted of an offence commonly have quite distinctive vulnerabilities and needs different from UK citizen residents.

For nationals from states outside of the EEA, it is necessary to distinguish people who cannot not be properly described as irregular migrants, with varying legal rights to remain. These include

- those with secondary types of immigration status - Indefinite Leave to Remain, Refugee Status, Exceptional Leave to Remain, Humanitarian Protection and Discretionary Leave

- asylum applicants - those people waiting a Home Office decision about their application

- those foreign nationals requiring visas; tourists, students, diplomats, people on work programmes.

Perhaps the only groups appropriately described as irregular migrants from amongst non-EEA countries, are undocumented migrants, illegal entrants and over-stayers. These include someone who has come to the UK without a visa, entry clearance or leave to enter or remain and who has not claimed asylum or someone who has overstayed a period of leave or breached conditions of leave and has had leave curtailed. Those arrested at the port of entry and asylum

\footnotetext{
${ }^{4}$ There is even a tendency to assimilate immigrants (for example) with people from minority ethnic communities who, as Wacquant ((1999: 216) puts it, are 'precisely not immigrants'.

5 'European Economic Area states comprise all EU member states, Norway, Liechtenstein and Iceland.

${ }^{6}$ For the legislation and background, see

http://europa.eu/legislation_summaries/justice_freedom_security/free_movement_of_persons_asylum_immigr ation/index_en.htm
} 
applicants whose applications have been refused are also termed by some as irregular migrants.

Any general term risks assimilating a wide and diverse group of people whose circumstances must be differentiated if their criminogenic and support needs are to be met. Yet whatever the legal entitlement to reside, the duty to respond fairly, appropriately and effectively to foreign nationals who are charged with or convicted of offences raises questions about the principle of rehabilitation. What this means and should mean in England and Wales - and the different significance and application of this principle in the case of foreign nationals - is the focus of the next section.

\section{The meaning of the rehabilitation principle in England and Wales}

Rehabilitation is among the statutory purposes of sentencing (Criminal Justice Act 2003, s. 142) and one of the principal aims of the National Offender Management Service of England and Wales. It has also been reaffirmed as a priority by the Coalition government that came into office in May 2010 and has called for a 'rehabilitation revolution' to break the cycle of reoffending (Ministry of Justice 2010).

Rehabilitation is usually associated with reform, with personal change. At the beginning of the what works initiatives in the 1990s in England, attention was focused on the particular ways of thinking that were believed to influence the behaviour of offenders and were therefore associated with their offending. If these patterns and habits of thinking could be altered, behavioural change might follow and desistance would eventually be accomplished (ref.) and it was in this sense that rehabilitation was commonly understood. More recently, however, attention has also been given to the importance of social capital: the opportunities that must be effectively available to people if they are to lead lawabiding lives. Changes in thinking will not be sufficient without fair access to the opportunities and resources of civil society. At a policy level, an important stimulus to this approach in UK was a report from the Social Exclusion Unit (2002) which drew attention to the many ways in which ex-prisoners were effectively denied opportunities to go straight. Their troubled lives, already marked by all kinds of disadvantage, were also constrained by social exclusion which was argued to be associated with further offending.

The government responded to the challenges of the Social Exclusion Unit's Report with an Action Plan to reduce reoffending (Home Office 2004). This identified a number of pathways out of crime - resources and opportunities that were critically linked with offending-related needs. Specifically these were said to be:

- accommodation

- education, training and employment

- mental and physical health

- drugs and alcohol

- finance, benefits and debt

- children and families of offenders

- attitudes, thinking and behaviour. 
These insights have been significantly developed by studies of desistance which strongly emphasise the place of social capital in rehabilitation (McNeill and Weaver 2010). Broader conceptions of rehabilitation are being advanced accordingly that recognise that the personal endeavours of offenders must be matched by the responses of a community that will support them and be willing to believe in the possibility of change (Raynor and Robinson 2009).

This expanded understanding of rehabilitation comes close to the conception advanced in an influential paper by McWilliams and Pease (1990) who saw rehabilitation as the restoration of the individual to their original rights. (This is well captured by the French expression rétablir dans ses droits, as McNeill [2011] notes.) Rehabilitation in this sense does not depend upon personal reform, but is an entitlement that follows from the completion of the lawfully imposed sentence. Understood in this way, rehabilitation is a right for exoffenders and conceptually quite distinct from the personal reform expected of them (see also Lewis 2005; Rotman 1994). And it is this conception of rehabilitation that better represents the original mission of probation, according to McWilliams and Pease, which was (and should still be) 'an expressive agency'(1990: 21) which stands for a restoration to rights.

But which rights? For much of this way of speaking about rehabilitation ignores the predicament of foreign nationals. What is the standing to which they are to be restored? As was argued earlier, any term used to refer to foreign nationals risks failing to distinguish among people with quite different rights and legal entitlements as well as varying needs and periods of settlement in England and Wales, many of which are likely to be associated with the prospects of their reoffending and of accomplishing desistance.

Access to each of the pathways just listed will typically be significantly different and much harder for foreign nationals, both in law and in practice. Immigration status is the key indicator in determining the entitlement and access of foreign nationals to public funds and services. Access to health, employment, financial benefits, accommodation and educational services are restricted and sometimes denied. Also in practice, whatever their formal entitlements, some people will struggle to communicate in English; families are likely to be absent or unable to offer support (perhaps especially relevant for unaccompanied children or young people); there may be no or few people in the community who are willing to offer assistance and advice, depending on whether there is an existing, established community who share the offender's national or cultural origins. Familiar policy objectives like rehabilitation and resettlement, then, have an entirely different significance and bring altogether different challenges for foreign nationals who offend.

\section{Irregular migrants, crime and conviction}

All major conurbations in England and Wales have significant proportions of residents born abroad, many of whom will have retained the nationality of their birth and be residing, legally, under various immigration statuses. For instance, there are estimates that over a quarter of London residents were born abroad. It is not surprising therefore that working with individuals from foreign national groups - whether EEA nationals, migrant workers, refugees and asylum seekers and people under a myriad of other immigration statuses - is mainstream, 
everyday work for London probation staff and other criminal justice services such as the police, courts and prison service.

There are no figures to suggest these groups are in general over- or indeed under-represented in offending or that they are more likely to commit certain types of offence ${ }^{7}$. Prevalence, then, is to a significant extent unknown and in the nature of the case likely to remain so. Even if the difficulties of definition (discussed above) could be clarified, there remain real problems in trying to determine the extent to which foreign nationals are involved in crime and their representation in criminal and judicial statistics. The relationship between 'true' levels of crime and recorded statistics is well known to be uncertain and complex in any case. (e.g. Maguire 2007).

Yet despite the inadequacy of statistical evidence, it is plausible to speculate that people settling in UK from abroad are likely to face problems which could lead to offending - perhaps especially when they are arriving from areas of the world with particular problems, like civil unrest, and where there are few community groups established in this country to offer welcome and support. New communities tend towards deprived metropolitan areas which are already characterised by high levels of economic hardship, unemployment and crime. Mere survival can be a challenge: a vivid example is the Housing Minister's recent assertion that half of all rough-sleepers in London are foreign nationals, mainly in London, Eastern European nationals (Shapps 2012). As the Social Exclusion Report noted, people denied opportunities to access services and to live within the law, may well be tempted to resort to illegal means to resolve their predicaments. In the same way (and for much the same reasons), it seems likely that new arrivals would be vulnerable to relatively high levels of criminal victimisation, although this attracts nothing like the same level of political attention or concern. Since there is no evidence of over-representation despite these many disadvantages and exigencies, it could be argued that foreign nationals may be peculiarly resistant to offending.

More specifically, there is anecdotal evidence about some concentrations of offences at certain times in certain locations. For example, since the enlargement of the EU in May 2007, some migrants have been duped into coming here for work - with various promises - and some of this group have ended up homeless and destitute, susceptible to drink and drugs and street level offending in metropolitan areas. Unaccompanied children who are asylum seekers can experience problems in settling without family support and be open, in their late teens / early 20s, to peer group pressure, sometimes leading to offending. There are examples of individuals no longer entitled to any state supports - for instance refused asylum seekers who have exhausted their appeal rights, but whom this country is not removing due to insecurity in their home country - who have offended (by working as illegal minicab drivers, for instance).

But all these generalisations need to be viewed and stated cautiously - foreign nationals who settle in this country have enough to contend with in the current political and social climate apart from being accused of disproportionately high

\footnotetext{
${ }^{7}$ Foreign nationals, however, are more likely to be imprisoned for certain types of offences than for others. Notably, many foreign nationals are held in prison for drug offences. Irregular migrants, by definition, are not entitled to be in the country and may therefore resort to fraud and forgery of documentation to conceal their status and / or to gain employment. There is also likely to be some incidence of other kinds of 'survival' offending.
} 
rates of offending and the ills of society laid at their feet. It is not accurate and it is not right to do so. The vast majority of migrants in England and Wales comprise, as a group, individuals who are employed in traditionally poorly paid areas of the economy, work long hours with poor working conditions and limited security of employment.

The monitoring of an offender's nationality by different criminal justice agencies in England and Wales is a complex picture. The nationality of an individual arrested is not automatically checked by an arresting officer unless they have specific grounds to undertake such checks. Therefore comprehensive statistics to indicate whether foreign national offenders are disproportionately represented at various stages of the criminal justice process in England and Wales are simply not available. The foreign national prisoner crisis of $2006^{8}$ was a milestone in policy development for both foreign national prisoners and indeed foreign national offenders in general. One of the various changes from 2006 has been the requirement that the prison and probation service improve their recording and use of nationality and immigration status in their work with offenders. In respect of probation, since 2006, the various case management systems in use have been able to record an offender's nationality and, for some, immigration status. The quality of such data is variable, however, depending, for instance, on whether it relies on the self-declared nationality of the offender or is verified through checks with the UK Border Agency and varies therefore between Probation Trusts. For London Probation Trust (LPT), data completion and quality have steadily improved so that in 2011, nationality is recorded in $84 \%$ of cases. A breakdown of these statistics, shows that $62 \%$ of LPT's caseload are recorded as British nationals and $22 \%$ as foreign nationals, this last group comprising $7.9 \%$ EEA nationals and $14.1 \%$ non-EEA nationals, with $16 \%$ data not known.

Nationality (but not immigration status) is also recorded in prison statistics which show that non-national prisoners are overrepresented in UK prisons. Towards the end of 2011 , there were 11,076 foreign nationals ( $13 \%$ of the total prison population) in the prisons of England and Wales. There were 650 women (15\% of the female prison population). These figures refer to all prisoners who are not of British nationality, including those who are or were lawfully resident before they were detained. They also include foreign nationals who have never been resident here and who, for example, have been arrested at ports of entry, usually as drug couriers. For instance, nearly half of all foreign national women in prison are there for drug offences (compared to about one-fifth of women of British nationality). (All figures from Prison Reform Trust 2011.)

These numbers have been increasing steadily over the past 20 years, rising to its present levels from an average of $6-8 \%$ in the early $1990 \mathrm{~s}$. The reasons for this are many and complex. Banks (2011) concludes that these increases cannot plausibly be attributed to the prevalence of offending by foreign nationals or the seriousness of their crimes. It is important to state clearly, then, that statistical information about the proportion of foreign nationals in prison is in no way relevant to trying to assess offending levels by individuals from newly established foreign national groups living in this country. There is no clear

\footnotetext{
${ }^{8}$ In 2006, there was a crisis in the Home Office regarding the management of foreign national prisoners in prisons throughout England and Wales. The then Home Secretary, Charles Clarke, resigned due to the failure to consider for deportation over 1,000 foreign national prisoners who had been released into the country without consideration by the UK Border Agency. The UK Border Act (2007) and the Criminal Justice and Immigration Act (2008) followed, increasing the probability of foreign national prisoners being deported.
} 
statistical evidence that individuals within migrant or newly established communities offend either more or less than individuals from other groups.

\section{Irregular migrants and the principle of rehabilitation}

In this section, it will be argued that while the rehabilitation principle is not framed differently in statute and case law, the implementation of law and policy commonly lead to differences in practice and in outcome. More generally, within the legal framework in England and Wales, there are no statutory differences in the powers available to courts when foreign nationals appear before them, but their experiences can be significantly different.

\section{Bail}

In general, discussions of prison populations often forget about remand prisoners. In English law, there is a presumption of bail - in other words, people should not be held in custody to await their trial unless there are specific reasons (defined by law) otherwise. One such reasons is the risk of absconding. While there is little or no evidence to show that foreign nationals might abscond, as Banks argues (2011: 195) "That foreign nationals lack the requisite antecedents and offence history to enable accurate risk assessment, coupled with a belief that they pose a greater risk of absconding than do British nationals, may result in remand and custody as the default option in many cases." Homelessness or unsettled accommodation can constitute other - and arguably more reasonable - grounds for a concern that defendants may abscond and be relatively much harder to apprehend subsequently.

\section{Pre-sentence reports (PSRs)}

Pre-sentence reports (PSRs) are normally prepared where a court is considering a custodial or a community sentence. That said, it is for the Court to decide whether to request a PSR or to sentence immediately and they may dispense with a PSR when a custodial sentence is considered inevitable and the court requires no information or risk assessment from a probation officer ${ }^{9}$. In some areas, probation staff may suggest that the Court would benefit from a PSR; in others they may not. How pro-active court probation staff are in this respect varies with their knowledge, confidence and competence and depends too on the Court's 'culture', which, in the Magistrates (lower) Court, is often set by the Bench Chair or by the Senior District Judge. There is anecdotal evidence that probation staff and sentencers view these matters differently when the defendant is a foreign national and a PSR is less likely to be requested,

\footnotetext{
9 The Criminal Justice Act 1991 required Courts to consider a PSR before passing a custodial sentence so that, for the first time, PSRs were provided by Probation Services as a matter of course on foreign national defendants at risk of custody. But this legislative requirement was soon removed by the Criminal Justice \& Public Order Act 1994. There was therefore only a brief period (1991-1994), when PSRs were routinely prepared on foreign nationals not usually resident in the UK, who had been arrested at Ports of Entry, primarily for drug trafficking and fraud offences (Abernethy and Hammond 1992). Once the 1994 Act was implemented, PSRs ceased to be provided almost immediately at the Crown Court, Croydon where those arrested at Gatwick Airport were sentenced. PSRs continued to be provided by Middlesex Probation Service for those arrested at Heathrow until the service was amalgamated into the London Probation Service in 2001 and Middlesex's specialist Foreign Nationals Unit was disbanded (Hammond 1994). In Crown Courts that cover arrests at Ports of Entry such as Heathrow and Gatwick Airports, Dover \& St Pancras International, PSRs have not therefore been expected or required, on foreign nationals not usually resident in the UK for drug importation offences, since the late 1990's.
} 
especially when the foreign national defendant is known or believed to have irregular immigration status.

In practice, the decision on whether or not to order a PSR is closely linked with a provisional view about the suitability of a community sentence and it appears that Courts are appreciably less likely to regard foreign nationals as suitable for community sanctions. The reasons for this are complex and contentious: it may be because Courts believe that foreign nationals with irregular immigration status will be unable to access public funds or work legitimately and are therefore unlikely to be able to complete a community sentence. (For example: will they be able to complete a community penalty or will they abscond or breach their order by leaving the country?) It is also possible that some Courts adopt a more punitive approach to foreign national defendants to encourage them to comply with immigration requirements to leave the country: time in prison, it may be believed, will facilitate deportation by the UK Border Agency (UKBA - the agency with the responsibility of enforcing immigration regulations). Again, some Courts may think that the risks posed by foreign nationals cannot be addressed through community sentences or may wish to emphasise deterrence in such cases - even though the chances of the message being hear by those who need to be deterred are slight.

Do these misgivings still have their effect when a report is prepared? As Probation Trusts' monitoring of their cases by nationality and immigration status improves, analysis of report recommendations, actual sentencing and order completion data are emerging. In London Probation Trust, early indications in an unpublished analysis (2012) are that PSR writers are less likely to recommend certain community penalties on foreign national offenders - notably supervision, attendance on offending behaviour programmes, drug or alcohol treatment requirements - than on UK offenders. Community Payback, on the other hand, is disproportionately recommended in PSRs for foreign nationals. What is maybe surprising, however, is that the probability of a sentencer following the recommendation from a probation officer for a community penalty does not seem to depend on an offender's nationality.

The reluctance of report writers to propose supervision and treatment programmes may be partly because of their perceptions of the difficulties of giving effect to these sanctions, as we shall consider below. A further possibility is that report writers may feel professionally de-skilled in working with offenders from unfamiliar groups, whose communities and cultures may be quite unknown. While there is no specific research into the role this plays in working with foreign nationals, Hudson and Bramhall (2005) have argued that, even in the case of British minority ethnic communities, report writers may represent certain groups in a stereotypical manner. In particular, discussions in reports around attitude towards the offence - especially with regard to remorse - showed marked differences between reports written on Asians and white offenders. They suggest there is no "discursive space"' in which perceptions of seriousness and remorse can be explored, inhibiting the process of movement towards an agreed account (Hudson and Bramhall 2005: 730). This leads to more distancing, sceptical turns of phrase ("He tells me that ..."; ".. according to him") as well as sometimes suppressing aspects that are indispensable to an understanding of the offence - for example, that an offence was a response to racist harassment. While the same formal areas are covered, the lens of interpretation is quite different. Many irregular migrants, of course, are white, but differences of 
culture and perhaps communication difficulties give comparable scope for stereotype. If cultural misunderstanding may take place even in circumstances where report writer and defendant share a nationality and a country of residence, it is all the more likely to be true in the case of foreign nationals and irregular migrants.

The general picture seems to be that, for foreign nationals and irregular migrants, report writers and sentencers favour Community Payback (unpaid work / community service) with its emphasis on punishment and reparation, rather than a supervision requirement (probation order) which has primarily rehabilitative aims. Welfare needs may be all too apparent, though very difficult to meet, while the possibility of addressing offending behaviour may seem altogether too difficult. As well as uncertainty about the relevance and appropriateness of using familiar approaches and techniques with people from other cultural backgrounds, whose attitudes and beliefs may be quite different, there may be difficulties in administering the sentence, including the additional time (and expense) of linguistic interpretation. The challenges of liaising with the UKBA may also be unfamiliar and daunting. Even so, when probation supervision includes on-going liaison between probation staff and the UK Border Agency's Local Immigration Teams during the management of the order, a community order can be a perfectly feasible option. The challenge for report writers is to explain this option clearly to Courts so that sentencers may be assured that there are many cases in which community sentences can manage the risks posed by foreign national offenders.

\section{Community penalties}

As we have seen, then, practice in Court takes place against a background assumption that foreign nationals and irregular migrants will not (or cannot) comply with the requirements of a community order, while the political climate takes removal to be the priority and it is assumed that imprisonment will facilitate deportation. Perhaps the biggest challenge here is for probation staff to understand the impact of nationality and immigration status on the management of community sentences on foreign national offenders. Many individual Probation Trusts, especially (though not exclusively) in the metropolitan areas, have produced staff guidance on the practice issues for working with foreign national offenders, including report writing. On EPIC, NOMS Probation's intranet, there is a Foreign Nationals section which provides information on how probation officers can contact and liaise with the UK Border Agency. Nevertheless, some probation staff may not have the additional knowledge and information to work effectively with foreign national offenders, to be able to recommend community sentences confidently and persuasively in their reports or to manage such orders effectively if they are made.

There are risks that uneven practice can reinforce the assumptions (among courts and probation staff) that foreign national are unsuitable for community sanctions. A full concept of rehabilitation, as we have seen, appreciates the importance of social capital in desistance. But how is this to be achieved when many foreign nationals and irregular migrants may be unable to work legitimately, excluded from and ineligible for education or training services, hard to engage and work with through traditional methods, and may have limited access to drug and alcohol treatment programmes due to funding issues and 
uncertain access to general health care? Again, compliance depends often on legitimacy (Bottoms 2001) and a failure to provide relevant and accessible services may lead to disaffection, non-compliance and breach.

It is therefore both unexpected and remarkable that the emerging London data suggest that, contrary to the usual assumptions, foreign nationals as a group are slightly more likely than UK citizens to complete their community sentences successfully. This is one of the most important and encouraging findings of this review and confirms that community sentences are feasible and appropriate when properly managed (London Probation Trust 2011).

\section{Prison and throughcare}

There are no prison instructions restricting access of foreign national prisoners to services, resettlement or rehabilitative, or to offending behaviour programmes. The nationality and immigration status of a prisoner should not disadvantage a prisoner. Nevertheless, reports by Her Majesty's Inspector of Prisons have described over a number of years how foreign national prisoners as a group do experience a different type of prison regime and restricted access to services compared with other prisoners (notably HMIP 2006, 2007). In terms of preparation for release for instance, pre-release schemes and programmes, when available, are less likely to be relevant since they are based on resettlement in the UK as opposed to deportation and resettlement abroad.

The impact of the Foreign National Prisoners crisis of 2006 has had a profound impact on both the management of foreign national prisoners and the increased focus on their deportation from the country. In legislative terms, the UK Borders Act 2007 added further powers, widening the criteria for the automatic consideration and presumption of deportation of foreign national prisoners. Three prisons were re-rolled and solely hold foreign nationals, with UKBA staff working in them to facilitate deportation and removal. Reports from Her Majesty's Inspectorate of Prisons point to significant shortcomings in their work in supporting rehabilitation and resettlement (see http://www.justice.gov.uk/publications/inspectorate-reports/hmi-prisons), even if in some establishments there are signs of improvement.

For a foreign national prisoner with irregular immigration status, discharge from prison in the UK may involve residence in UKBA-sourced accommodation or to an unsettled address. In the absence of family or community ties or other legal entitlement to housing, ex-prisoners will often be dependent on the support of community or faith groups. Insecurity of tenure and residence will make other opportunities effectively inaccessible, as well as undermining motivation and the possibilities of pursuing resettlement goals. Also to be noted is the marked increase in numbers of foreign national prisoners held in custody after completing the sentence for their offence(s) pending deportation, (under the Immigration Act 1971). There were an average of 1700 ex-foreign national prisoners in this position in 2010, up to 600 remaining in prisons with another 1200 being transferred to Immigration Removal Centres (see also Banks 2011). Such detention under Immigration Act powers can, in theory, continue indefinitely until release by executive decision of the UK Border Agency or by an Immigration \& Asylum Tribunal. ( Bail for Immigration Detainees ) 


\section{Mental health, alcohol and drug treatment}

While there are a few special sentences available to courts in England and Wales in dealing with mentally disordered offenders, many offenders with mental health problems are sentenced to just the same range of sanctions as other convicted offenders (Canton 2008). The interface of the criminal justice and mental health systems is already perilous for some people, whose health needs are reinterpreted as risks and who may be sentenced to disproportionately severe penalties on that account. It is known too that for some British minority ethnic communities access to mental health services is more likely to be through the criminal justice system than through medical services (for example, Sashidharan 2003). While reliable data are hard to come by, it seems altogether likely that the position of irregular migrants is at least as difficult.

If an individual is 'ordinarily resident' in the UK, they should have access to the same alcohol and drug treatment that British nationals have through their community orders. 'Ordinarily resident' includes people with Indefinite Leave to Remain, convention refugee status, Exceptional Leave to Remain, Humanitarian Protection and Discretionary leave, asylum seekers, EU worker, students and their families. This leaves irregular migrants, illegal entrants and visa overstayers with particular problems in receiving drug and alcohol treatment - and indeed access to health care more generally, with a liability to pay in certain circumstances. However, the situation is complex, varies between areas and with increasing pressure on health services budgets, the situation is far from resolved or clear.

Throughout this section it has been argued that, while the criminal law does not directly prescribe that foreign nationals should be dealt with differently, in practice they are often significantly disadvantaged. Does this amount to discrimination? The law recognises that discrimination can take different forms and indirect discrimination, which is often of particular relevance in scrutinising criminal justice, occurs when, irrespective of intention, "a provision, criterion or practice" puts people at a particular disadvantage, where it cannot be shown that the provision, criterion or practice is a proportionate means of achieving a legitimate aim. (See Equality and Human Rights Commission for the legal framework and guidance.) The experiences of foreign nationals in the criminal justice system could be described as a form of indirect discrimination since criminal justice practice, rather than legislation, does set foreign nationals at disadvantage. The question then becomes whether this is proportionate to any legitimate aim.

\section{Rehabilitation for foreign nationals?}

In England and Wales there are no explicit sentencing restrictions on foreign nationals or indeed irregular migrants as a group, as there are in some other countries, to limit their access to community sentences. Yet the principle of rehabilitation, in practice if not in law, is significantly attenuated for people of foreign nationality and for irregular migrants. It is as if the political undertaking to work toward 'offender reintegration' is displaced by a priority to exclude and remove those who are not British citizens. An indication of this political priority is to be found in the UKBA Strategy which includes in its strategy a commitment to "Considering with partners, including the Crown Prosecution Service, the most 
effective use of out of court disposals such as cautions together with immigration powers, to remove low level foreign national offenders as an alternative to prosecution." (UKBA 2010: 8 - emphasis added). The ethical and legal basis for this approach must be questionable.

The consequences for foreign nationals can be oppressive, as well as for their families and especially for their children. One of the most troubling and unacceptable consequences is the criminalisation of people who have been exploited or trafficked and have sought survival through work in illegal activities and / or had to use fake documents. Once discovered, these people - perhaps disproportionately women - are treated as offenders with no regard to their vulnerability and undoubted status as victims of crimes against them (Prison Reform Trust and Hibiscus 2012).

How the rehabilitative principle should best be represented for foreign nationals is by no means straightforward, as how the criminal justice system deals with them is so intimately bound up with highly politicized environment surrounding crime and 'being foreign'. Offenders of whatever nationality should be sentenced fairly and proportionately, depending on the seriousness of their crime and how their risk to the community can best be addressed. The priority should be to treat people lawfully, justly and well, recognising and respecting the circumstances that have brought them to England - for instance, exercising their treaty rights, if citizens of EU states, to live and work in other member countries, or, in the case of refugees and asylum seekers, coming here in response to circumstances in their originating country.

The reasons for any individual's offending should be investigated through a PSR, with all sentencing options to be considered to support their rehabilitation and desistance and to decide what can best be done to protect the public. Deportation, to be sure, is sometimes an appropriate course of action, but even here it must take place with due regard to the future lives of offenders and their dependents. Wherever possible, this should include considered liaison with probation / criminal justice social work staff in the country to which they are returning. To neglect this is unethical and amounts to the exportation of problems and indeed sometimes of risks. To take seriously the value of protecting the public must include having regard to the well-being of the public in other nations. In this connection, the implementation of the EU Framework Decision 947 in the EU, requiring active liaison among member states, could contribute to developing a framework for the transfer of community sanctions and measures. At the same time, it should be borne in mind that many of the most vulnerable foreign nationals in England and Wales are from countries outside the EU and often well beyond the borders of Europe.

\section{Concluding comments}

In this paper, we have tried to argue that general expressions like foreign nationals or irregular migrants include people in widely diverse circumstances and with differences in their individual needs, in their legal standing and in the impact of their offending. Since these terms can have a significant impact on whether an individual passing through a country will receive just and proportionate treatment, they should be used with care and with clarity by criminal justice professionals. 
Some foreign nationals have been tricked or coerced into an illegal attempt to enter the country and into crime. Instead of recognising this, policy and practice have been preoccupied with disowning responsibility for people who are commonly needy and vulnerable and instead simply focus on trying to remove them.

While no state wants irregular migrants to offend or re-offend, policies can create an environment where this group are increasingly likely to do so because lawful ways of living are effectively denied them - lack of legitimate employment, access to public funds, training opportunities, health care, settled accommodation. This must raise the question whether government policy is guided by a principle of rehabilitation in these cases. The tone and content of policy demonstrates rather that foreign nationals with irregular immigration status are expected to cooperate 'voluntarily' with their departure or removal, not to settle or integrate successfully.

As O'Nolan astutely remarks "Increasingly restrictive asylum laws and barriers to employment for third-country nationals have also been used to reduce immigration flows. The efficacy of these measures is unclear as it is possible that reducing legitimate access to EU countries may increase levels of irregular migration, and so increase the size of a marginalised group of people in society whose exclusion from a web of social supports may make them more likely to resort to criminal offending." (2011: 386 emphasis added.) These reflections expose the radical limitations of the criminal law in responding to problems of complex social origin. Criminalising, arresting and detaining irregular migrants does not reduce their number, but it does bring any number of unhappy consequences for them, for their dependents and, since some current practices are criminogenic in their consequences, for victims of crime. 


\section{References}

Abernethy, R. and Hammond, N. (1992) Drug Couriers: a role for the Probation Service, Middlesex Probation Service

Bail for Immigration Detainees http://www.biduk.org

Banks, J. (2011) 'Foreign National Prisoners in the UK: Explanations and Implications', Howard Journal 50 (2): 184 - 198

Blair, T. (2006) Speech on Criminal Justice Reform, delivered in Bristol $23^{\text {rd }}$ June 2006 as reported in The Guardian 23.06.2006, available online at http://www.guardian.co.uk/politics/2006/jun/23/immigrationpolicy.ukcrime1 (accessed September 2012)

Bottoms, A. (2001) 'Compliance and community penalties', in Anthony Bottoms, Loraine Gelsthorpe and Sue Rex (eds.), Community Penalties: Change and Challenges, Cullompton: Willan

Canton, R. (2008) 'Working with Mentally Disordered Offenders' in Simon Green, Elizabeth Lancaster and Simon Feasey (eds.) Addressing Offending Behaviour: Context, Practice, Values, Cullompton: Willan Publishing

Davis, J. (1980) 'The London Garotting Panic of 1862: A Moral Panic and the Creation of a Criminal Class in mid-Victorian England' in V. Gatrell, B. Lenman and G. Parkers (eds.) Crime and the Law: The Social History of Crime in Western Europe since 1500, London: Europa

Equality and Human Rights Commission - http://www.equalityhumanrights.com/

HMIP (Her Majesty's Inspectorate of Prisons) (2006) Foreign national prisoners:

a thematic review, available online at

http://www.justice.gov.uk/downloads/publications/hmipris/thematic-reports-andresearch-publications/foreignnationals-rps.pdf (accessed September 2012)

HMIP (2007) Foreign national prisoners: A follow-up report, available online at http://www.justice.gov.uk/downloads/publications/hmipris/thematic-reports-andresearch-publications/foreign nationals follow-up1-rps.pdf (accessed September 2012)

Hammond, N. (1994) Pre-sentence Reports on Non-UK Resident Foreign Nationals: their purpose, value \& effectiveness, Cropwood Fellowship, Institute of Criminology, University of Cambridge

Hester, S. and Eglin, P. (1992) A Sociology of Crime, London: Routledge

Home Office (2004) Reducing Re-offending: National Action Plan http://www.thelearningjourney.co.uk/reducing-reoffending-action-plan.pdf/file view (accessed September 2012)

Hudson, B. and Bramhall, G. (2005) 'Assessing the "Other": Constructions of "Asianness" in Risk Assessments by Probation Officers', British Journal of Criminology, 45 : 721 740

Lewis, S. (2005) 'Rehabilitation: Headline or footnote in the new penal policy?', Probation Journal, 52 (2): 119 - 135 
London Probation Trust (2011) Equalities Monitoring Report: April - October 2011, available online at http://www.londonprobation.org.uk/pdf/LPT\%20Equalities\%20Monitoring\%20Report Jan2012.pdf (accessed September 2012)

Maguire, M. (2007) 'Crime Data and Statistics' in Mike Maguire, Rod Morgan and Robert Reiner (eds.) The Oxford Handbook of Criminology ( $4^{\text {th }}$ edition), Oxford: Oxford University Press

McLynn, F. (1991) Crime and Punishment in Eighteenth Century England, Oxford: Oxford University Press

McNeill, F. (2011) 'Probation, Credibility and Justice', Probation Journal 58 (1): 9 - 22

McNeill, F. and Weaver, B. (2010) Changing Lives? Desistance Research and Offender Management - available online at http://www.sccjr.ac.uk/pubs/Changing-LivesDesistance-Research-and-Offender-Management/255 (accessed September 2012)

McWilliams, W. and Pease, K. (1990) 'Probation practice and an end to punishment', Howard Journal, $29: 14-24$

Ministry of Justice (2010) Breaking the Cycle: Effective Punishment, Rehabilitation and Sentencing of Offenders, Cm. $7972-$ available online at http://webarchive.nationalarchives.gov.uk/20120119200607/http:/www.justice.gov.uk/c onsultations/docs/breaking-the-cycle.pdf (accessed September 2012)

O'Nolan, C. (2011) 'Penal Populations in a World in Motion: The Case of the Republic of Ireland' Howard Journal 50 (4): 371 - 392

Pearson, G. (1983) Hooligan: A History of Respectable Fears, London: Macmillan

Prison Reform Trust (2011) Bromley Briefings Prison Factfile, available online at http://www.prisonreformtrust.org.uk/Publications/Factfile (accessed September 2012)

Prison Reform Trust and Hibiscus (2012) No Way Out, available online at http://www.prisonreformtrust.org.uk/Publications/vw/1/ItemID/149 (accessed September 2012)

Sashidharan, S. (2003) Inside Outside: Improving mental health services for black and minority ethnic communities in England, available online at

http://www.dh.gov.uk/en/Publicationsandstatistics/Publications/PublicationsPolicyAndGui dance/DH 4084558 (accessed September 2012)

Social Exclusion Unit (2002) Reducing re-offending by ex-prisoners, Office of the Deputy Prime Minister, available online athttp://www.thelearningjourney.co.uk/reducing report.pdf/file view (accessed September 2012)

Raynor, P. and Robinson, G. (2009) Rehabilitation, Crime and Justice, Basingstoke: Palgrave Macmillan

Rotman, E. (1994) 'Beyond Punishment' in R.A. Duff and D. Garland (eds.) Reader on Punishment, Oxford: Oxford University Press

Shapps, G. (2012) Over half of London's rough sleepers now non-UK nationals available online at http://www.communities.gov.uk/news/corporate/2093807 (accessed September 2012) 
UK Border Agency (2010) Protecting Our Border, Protecting The Public: The UK Border Agency's five year strategy for enforcing our immigration rules and addressing immigration and cross border crime, available online at http://tinyurl.com/c6p8pht (accessed September 2012 